\title{
A reforma da administração dos recursos humanos públicos portugueses após o fim do estado novo: uma evolução histórica
}

\author{
Reformofhuman resourcesmanagementin \\ the portuguesepublic sectorafterthe end of \\ the "estado novo": a historical evolution
}

Miguel Lira ${ }^{1}$

Ana Roso ${ }^{2}$

\section{Resumo}

O presente trabalho tem como objetivo principal concorrer para o incremento do conhecimento sobre a evolução ocorrida na administração dos recursos humanos públicos portugueses após a queda do Estado Novo (1974) até ao presente, mormente quanto à influência que os paradigmas da New Public Management e da Governance tiveram nas mudanças registadas neste domínio ao longo das últimas décadas, para além de identificarmos as mais recentes medidas de austeridade adotadas no plano político, reflexo da forte crise económica e financeira que assola Portugal, com repercussões diretas no "funcionalismo público" português e sua administração. Para uma melhor concretização destes objetivos, iremos realizar esta análise através da utilização de três períodos perfeitamente balizados: 1974 até 1985; 1985 até 2008, e entre 2008 e o presente. Posto isto, este ensaio será baseado em pressupostos teóricos interpretativos, adotando como metodologia uma abordagem qualitativa e como método de investigação o bibliográfico.

Palavras-chave: Administração dos Recursos Humanos Públicos. Portugal. Reforma Administrativa. New Public Management. Governance.

Titulação: Doutorando em Gestão e Mestre em Contabilidade e Auditoria Cargo: Docente - Equiparado a Assistente Vínculo Institucional: Instituto Superior de Contabilidade e Administração de Coimbra | Instituto Politécnico de Coimbra Morada: Rua Filinto Elísio, n. ${ }^{\circ} 29$, 2. ${ }^{\circ}$ Esq.; 3830-305 Ílhavo; PORTUGAL E-mail: mlira@iscac.pt

2 Titulação: Doutoranda pela Faculdade de Direito da Universidade de Coimbra Cargo: Bolseira de Investigação de Doutoramento Vínculo Institucional: Fundação para a Ciência e Tecnologia Morada: Rua Paulo Quintela, n. ${ }^{\circ}$ 306, 3. ${ }^{\circ}$ C, 3030-393 Coimbra; PORTUGAL E-mail: ana.roso@ gmail.com 


\section{Abstract}

The present paper has asmain objective the increaseof knowledge about the evolution in the management ofPortuguese publichuman resourcesafter the fallof "Estado Novo"(1974)to the present, especiallyregarding to the influencethatthe paradigms ofNew PublicManagementandGovernancehave had in the changesinthis field overthe past decades, in addition toidentifyingthe latestausterity measures adoptedin the political plan, reflecting the strong economic and financial crisiswhich currentlyplaguingPortugal, withdirect repercussionson thePortuguesecivil serviceand its administration. For a better concretization of these objectives, we willperform this analysisusingthreeperfectlywell-markedperiods: 1974 to1985;1985 to2008; andfrom 2008 to thepresent. That saidthis paper will be based oninterpretativetheoretical assumptions, adopting as methodology a qualitative approach and as research method the bibliographic one.

Keywords: PublicHuman Resource Administration. Portugal. Administrative Reform. New Public Management. Governance.

\section{Aspetos introdutórios, objetivos e metodologia}

Uma das principais causas do mau funcionamento do sector público português, segundo Tavares (2003, p. 22), resulta de uma "deficiente organização/articulação/coordenação” das organizações públicas, para além das que resultam de um planeamento deficiente. Contudo, o mesmo autor salienta que, nos últimos anos, tem-se assistido a uma evolução positiva mediante um reforço da cultura da responsabilidade e da qualidade dentro do sector público, para além de introdução e/ou melhor aplicação de alguns instrumentos, como planos de atividade, balanço social, relatórios de atividades, entre outros. Essas alterações resultam de uma reforma administrativa que incidiu sobre serviços, estruturas, estatutos, instrumentos de gestão, forma de organização do próprio sector e da própria administração dos recursos humanos públicos disponíveis (FERRAZ; ALEXANDRE, 2008). Esse processo de reforma anda em linha, principalmente, com as doutrinas da New Public Management e do paradigma da Governance, tendo marcado todos os programas governamentais das últimas décadas e figurando como um dos grandes objetivos de cada legislatura após o 25 de abril de 
1974, não obstante a "cor política" dos partidos no poder (MADUREIRA; FERRAZ, 2010a).

Todavia, esse processo reformatório não possuiu a mesma sagacidade ao longo do período aqui em análise. Se existiram períodos mais prolíferos, outros houve menos férteis em reforma, designadamente quanto ao que à administração dos recursos humanos diz respeito. Essa perspetiva transparece no artigo de Isabel Corte-Real (2008), denominado "Public management reform in Portugal: successes and failures", visto que a autora propõe uma periodização das reformas preconizadas em Portugal, após a revolução de 25 de Abril de 1974, em cinco períodos distintos, a saber: primeiro período:1974-1979; segundo período: 1980-1985; terceiro período: 1985-1995; quarto período: 19962001; quinto período: 2002-2008.

Essa periodização, no entanto, não abrange os dias de hoje, cessando no ano de 2008. Muito ironicamente, esse ano marca um ponto de viragem não só nacional, mas, igualmente, mundial: ficou marcado pelo maior colapso financeiro e económico global desde a Grande Depressão que se iniciou em 1929 (FRIEDMAN; FRIEDMAN, 2010; CROTTY, 2009). Perante esse cenário, apelidado por muitos de catastrófico, achamos por bem adicionar um sexto período: 2008 até ao presente, mais que não seja pelas inúmeras e profundas alterações sentidas dentro da esfera pública portuguesa diretamente resultantes dessa crise e do resgaste financeiro do nosso país pela Troika, ou Triunvirato, composto pela Comissão Europeia, pelo Banco Central Europeu e pelo Fundo Monetário Internacional (FMI).

De forma a evitar demasiada pormenorização, abordaremos a reforma administrativa portuguesa e, mais especificamente, a Administração dos Recursos Humanos (ARH), com base num desdobramento mais simplista de três vagas, até porque, das próprias palavras de Corte-Real (2008), podemos considerar que esse movimento reformativo teve duas velocidades completamente distintas: uma entre 1974 e 1985 e outra para os anos subsequentes até 2008. A essas duas acrescentaremos uma terceira vaga, que incluirá os anos de 2008 até ao presente. 
Por outro lado, essa divisão também vai de encontro aos nossos objetivos para este trabalho. Desde logo, pretendemos analisar a reforma administrativa portuguesa depois da revolução de 25 de Abril de 1974 que pôs fim ao regime do Estado Novo, concretamente quanto às mudanças introduzidas na sua ARH. Nesse âmbito, iremos direcionar os nossos esforços para a averiguação sobre o grau de ascendência dos dois principais paradigmas que serviram de base às reformas do sector público desde a década de oitenta do século $X X$ por esse mundo fora, ou seja, temos por objetivo analisar a influência das doutrinas da New Public Management e do paradigma da Governance nas alterações preconizadas na ARH do sector público português. Por fim, tentaremos identificar algumas das mais recentes medidas de austeridade adotadas no plano político, devido à forte crise económica que o assola o país e o seu reflexo na função pública.

Tendo em conta tais objetivos, a metodologia aplicada está em conforme. Antes de mais, temos de considerar que por metodologia deve entender-se como a forma geral de estudar um problema (SILVERMAN, 2001), consistindo no método e nas técnicas que o investigador utiliza para realizar a pesquisa, enquanto a pesquisa não é mais do que o conjunto de investigações, operações e trabalhos, quer sejam a um nível intelectual ou prático, cujo objetivo seja a descoberta de novos conhecimentos, a invenção de novas técnicas e a exploração ou a criação de novas realidades (KOURGANOFF, 1990). Neste estudo, o protocolo utilizado na pesquisa respeitou os seguintes trâmites, de acordo com a conceção de Raupp e Beuren (2006): descritiva, quanto aos objetivos; bibliográfica, quanto aos procedimentos; qualitativa, quanto à abordagem do problema. Desenvolvendo essa questão, podemos salientar que, para Raupp e Beuren (2006), a pesquisa descritiva configura-se como um estudo intermediário entre a pesquisa exploratória e a explicativa, isto é, não se apresenta tão preliminar como a primeira nem tão aprofundada como a última. Ainda segundo esses autores, as pesquisas bibliográficas são desenvolvidas mediante material já trabalhado, ou seja, fontes de evidência secundárias, principalmente livros e artigos científicos (técnicos e/ou académicos). Nesse aspecto, podemos também considerar a opinião 
de Cervo e Bervian (2002), que indicam que a pesquisa bibliográfica explica um problema a partir de referenciais teóricos publicados em documentos e pode ser realizada independentemente, ou como parte da pesquisa descritiva ou experimental. Por seu lado, a investigação qualitativa é aquela que não utiliza instrumento matemático, estatístico ou econométrico algum (RAUPP; BEUREN, 2006), requisitos que, na prática, são preenchidos pelo presente estudo, possibilitando a sua classificação como uma pesquisa com uma abordagem metodológica qualitativa. Em resumo, podemos considerar que o atual trabalho visa concorrer para o incremento do conhecimento sobre a evolução ocorrida na administração dos recursos humanos públicos após a queda do Estado Novo até ao presente, sendo baseado em pressupostos teóricos interpretativos, adotando como metodologia uma abordagem qualitativa e como método de investigação o bibliográfico.

Para além desta secção inicial introdutória, o texto está estruturado em mais cinco secções. As secções segunda, terceira e quarta oferecem uma panorâmica - perfeitamente balizada em termos temporais - das principais reformas ocorridas na função pública portuguesa em cada um dos períodos analisados. Posteriormente, são analisados os principais entraves e obstáculos às tentativas de abraçar os paradigmas da New Public Management (NPM) e Governance. A exposição termina com a discussão das principais questões a reter e apresentação das conclusões, limitações e recomendações essenciais do trabalho.

\section{A primeira vaga: $1974-1985$}

O primeiro dos períodos previstos por Corte-Real (2008) compreende os anos posteriores à Revolução dos Cravos, designadamente, o ciclo 1974-1979. De notar que essa revolução ditou o fim de mais de meio século de ditadura no nosso país, onde prevaleciam, desde 1933, os ideais de António de Oliveira Salazar e do seu Estado Novo de partido único, a União Nacional (ROCHA; ARAÚJO, 2007; TAVARES; ALVES, 2006, ROCHA, 1991). Esse Estado caraterizava-se por ser do tipo corporativista, em que o sector público era 
concebido como um instrumento de controlo burocrático ao dispor desse sistema político autoritário (ROCHA, 2009, 1991), no qual as funções geralmente associadas a um estado social, como segurança social, saúde, educação ou habitação, "eram incipientes ou não abrangiam a totalidade da população" (ARAÚJO, 2005, p. 2).

Nesse primeiro período, denotava-se uma certa preocupação com uma alteração da ordem social e das estruturas públicas, compreensível nesses momentos pós-revolução, fortemente marcados por ideologias políticas de "esquerda". Essas preocupações eram, essencialmente, três: destruir o poder dos grandes e influentes grupos económicos, incluindo os que detinham posições de monopólio, drástico programa de nacionalizações (FRANCO, 1994); desmantelar os serviços ideologicamente conectados com o anterior regime, em particular as atividades de censura; e a construção de um estado social: o Estado Providência (ROCHA; ARAÚJO, 2007).

No que concerne à criação de um Estado de Direito Social, o seu ponto de partida foi a aprovação da já referenciada nova Constituição da República Portuguesa (CRP) pela Assembleia Constituinte, em abril de 1976. Foi essa Constituição e as suas promessas de uma nova e vasta gama de novos direitos sociais que permitiram a introdução do Estado Providência em Portugal. Assim, nos anos que restavam dessa década de setenta e durante a década seguinte, a prioridade política passou pela ampliação do alcance e âmbito dos serviços públicos prestados e bens públicos fornecidos (TAVARES; ALVES, 2006).

A ampliação do papel e do tamanho do Estado daqui resultantes não foi devidamente acompanhada pela necessária renovação das estruturas administrativas, do modelo de administração e de funcionamento de todo o sector público (ARAÚJO, 2005), sem falar que resultou no aumento da despesa pública, como aliás já tinha acontecido em muitos outros países europeus que adotaram este modelo de Estado a partir do fim da II Guerra Mundial. Portugal estava, assim, em claro contraciclo relativamente aos seus congéneres europeus, o que também ficou patente na evolução dos números relativos à função pública. Dessa 
forma, a não existência de um Estado Providência durante a ditadura do Estado Novo trouxe contornos insólitos para o funcionalismo público após a revolução. Ao contrário do que acontecia na maioria dos países ocidentais, o número de funcionários públicos portugueses aumentou na década de 80 e de 90 do século XX, muito por causa das nacionalizações e da expansão (tardia) do Estado Providência no nosso país (CORTEREAL, 2008). Num período de vinte anos, entre 1979 e 1999, o número de funcionários públicos quase duplicou (ROCHA, 2009).

Outras das preocupações sentidas com a função pública nesse período passavam pela integração de quase 40.000 funcionários públicos chegados das colónias ultramarinas, de entre os 600.000 cidadãos portugueses que viviam nessas colónias e que tiveram de retornar devido à independência desses territórios, confirmada nesse período; pela estagnação das carreiras no funcionalismo público devido à ausência de promoções ou de outras recompensas (Corte-Real, 2008); e pelas baixas remunerações, compensadas, em parte, por áreas de privilégio, como a ausência de taxação dos ordenados (ONGARO, 2009; PINTO, 1994).

A necessidade da reforma dessa desatualizada e obsoleta função pública era por demais evidente. Assim, essa reforma começou em 1979 com a criação de um sistema transparente de carreiras públicas, bem como através da definição de procedimentos e condições comuns que possibilitavam um ingresso e recrutamento igualmente transparente e o progresso dentro das carreiras, num misto de mérito e antiguidade como pontos relevantes para a promoção (ROCHA; ARAÚJO, 2007).

Há ainda a realçar nesse primeiro período a criação da DireçãoGeral da Função Pública, através do Decreto-Lei n. ${ }^{\circ} 746 / 74$, de 27 de dezembro. Esta ficou incumbida de proceder aos estudos conducentes à definição da política geral de pessoal e à caraterização e aperfeiçoamento das respetivas técnicas de gestão e formação de pessoal; elaborar as normas reguladoras das condições gerais de prestação do trabalho; definir as regras que devem presidir à criação e reformulação dos quadros, carreiras e categorias de pessoal; assegurar a coordenação 
estatutária das políticas sectoriais de gestão do pessoal; assegurar um sistema de gestão pessoal dos quadros da administração pública; promover a institucionalização de um sistema de administração da função pública; e realizar os estudos e tomar iniciativas relativas ao sistema de segurança social dos servidores da função pública em coordenação com os departamentos adequados.

Após um segundo período (1980-1985), em que as reformas de modernização se circunscreveram a aspetos técnicos ao nível do orçamento ou da regulamentação da função pública, entre outras áreas, sendo esse cenário agravado pela sua pobre implementação (ONGARO, 2009), surge um mundo muito mais rico e vasto em termos de modernização e reforma administrativa. Esta tinha por base muitos dos valores e doutrinas presentes na NPM, quase uma década depois de o mesmo processo reformatório se ter iniciado em países como Reino Unido, Austrália, Nova Zelândia, Canadá etc. (MENDES, 2010; ARAÚJO, 2001). Para essa viragem, muito contribuiu a entrada na Comunidade Económica Europeia - atual União Europeia (UE) - em 1986, sem esquecer o papel desempenhado pela estrutura de missão que tinha como responsabilidade a dinamização da reforma administrativa em Portugal: o Secretariado para a Modernização Administrativa (ARAÚJO, 2005; CARAPETO; FONSECA, 2006). É esse novo mundo que passaremos a explorar no próximo ponto deste trabalho.

\section{A segunda vaga: $1985-2008$}

No nosso trabalho, optámos por considerar o ano de 1985 como ponto de viragem, como o faz, aliás, Corte-Real (2008). Mas e porquê? Porque foi a 6 de novembro de 1985 que o X Governo Constitucional português tomou posse, liderado por Aníbal Cavaco Silva. Na nossa opinião, a génese para as reformas visíveis na década de 1990 estão aqui. A partir daqui, as ideias inseridas no campo doutrinário da NPM e, posteriormente, da Governance, bem como as experiências de reforma noutros países, passaram a influenciar a reforma administrativa em Portugal (Mendes, 2010; Ferraz e Alexandre, 2008; Rocha e Araújo, 2007; 
Araújo, 2001), tendo como foco a desburocratização, as privatizações e a necessidade de proximidade e de transparência para com o cidadão (MADUREIRA; FERRAZ, 2010A; ARAÚJO, 2001), sendo que essa aproximação foi, muitas vezes, uma aproximação física (veja-se o caso das Lojas do Cidadão) (FERRAZ; ALEXANDRE, 2008).

Agora, um pequeno parêntese para - muito brevemente apresentar estes dois modelos de administração pública supra mencionados.

O modelo da NPM - ou Nova Gestão Pública (NGP) - serve de rótulo às diversas reformas que ocorreram a partir de finais da década de setenta do século XX em países com diferentes sistemas políticos e económicos, como EUA, Coreia do Sul, Reino Unido, França, Brasil, Austrália, Suécia, Nova Zelândia ou Canadá (TALBOT, 2009; POLLITT; BOUCKAERT, 2004; SULEIMAN, 2003; BARZELAY, 2001; KABOOLIAN, 1998; KETTL, 1997; AUCOIN, 1996; HOOD, 1991). Podemos considerar que a NPM refere-se a um simulacro de alocação de recursos por mercados ou quase-mercados competitivos que se adequava aos ventos neoconservadores que sopravam e cuja dispersão global se deve ao inerente apelo das suas ideias, mas também, em grande medida, pelo apoios e orientações demonstrados por organizações mundiais como a Organização para a Cooperação e Desenvolvimento Económico (OCDE), o Banco Mundial, o FMI ou as Nações Unidas, para além de outras instituições mundiais e regionais (TALBOT, 2009; LYNN, 2005; POLLITT; BOUCKAERT, 2004; HOOD, 1998; KICKERT, 1997; HOOD E JACKSON, 1991; POLLITT, 1990), o que só evidencia o papel que essas organizações tiveram nesse movimento global de reforma (MCNUTT; PAL, 2011). Outros autores acrescentam que as razões para a sua difusão também têm de ser atribuídas a escolhas racionais realizadas pelos formuladores de políticas em resposta à crise fiscal e a uma forma de isomorfismo institucional (BACH; BORDOGNA, 2011;POLLITT, 2001).

De um ponto de vista teórico, os pontos nevrálgicos da complexa amálgama de teorias e ideologias que compõem a NPM foram claramente sintetizados, conjugados e apresentados em 1991 por 
Christopher Hood através do seu artigo "A public management for all seasons?". O conceito central do argumento de Hood (1991) era simples: para assegurar um desempenho eficiente, o sector público devia pedir emprestado as ferramentas, os valores e os termos utilizados no sector privado. Subjacente a essa nova filosofia está, portanto, a crença de que as práticas, métodos e princípios utilizados na gestão do sector privado são superiores às usadas na administração do sector público (RUBIN; KELLOUGH, 2012; DENHARDT; DENHARDT, 2007, 2000; OSBORNE, 2006; POLLITT; BOUCKAERT, 2004; HOOD, 1995B; PETERS, 1996). Enfim, a NPM afasta-se dos modos tradicionais de legitimação da burocracia pública, como as garantias processuais na discricionariedade administrativa, em favor da confiança no mercado e nos métodos e ideias seguidos no sector privado, expressas na linguagem do racionalismo económico (HOOD, 1995a).

Para finalizar, podemos acrescentar que, nas reformas administrativas apoiadas nas doutrinas subjacentes à NPM, encetadas em diversos pontos do mundo, foi observada a utilização de instrumentos tais como gestão por resultados, introdução de medidas de desempenho (OSBORNE, 2006; BROWN, 2004; ARAÚJO, 2004, 2002A), desregulamentação, contratos com base no desempenho, competição, incentivos de mercado, orientação para o consumidor ou cliente (ROSENBLOOM; KRAVCHUCK; CLERKIN, 2009; OSBORNE, 2006; PETERS, 2001; KABOOLIAN, 1998), ou privatização (BACH; BORDOGNA, 2011; RAINEY; CHUN, 2005; RAINEY, 1999), para além dos sistemas de prestação de serviços e bens públicos e a formulação e implementação das políticas públicas poderem ser analisados como uma série de transações com todas as características de contratos negociados (LANE, 2000).

As críticas dirigidas à NPM, designadamente aquelas que incluíam um largo espetro de denúncias dos excessos do managerialismo, que colocavam em xeque questões tais como a cidadania, democratização, o papel a desempenhar pelos cidadãos, o accounting democrático e aspetos similares (LYNN, 1998), estiveram na base da emersão de um novo paradigma de administração pública. É nesse contexto que o 
emergente modelo denominado de Governance, ou Governação, tendo como caraterística imperante o facto de as redespassarem a dominaras políticas públicas (LÖFFLER, 2009; ARAÚJO, 2007). Dessa forma, a Governação repousa mais na cooperação entre diversos atores do que sobre a unilateralidade, isto é, esse novo modelo reconhece a existência de um cenário em que múltiplos intervenientes estão aptos para contribuir no desenvolvimento das funções públicas (GREENAWAY; SALTER; HART, 2007; RHODES, 1997). Fattore, Dubois e Lapenta (2012, p. 219) acrescentam: "a difusão da ação administrativa, a multiplicação de parceiros administrativos e a proliferação da influência política fora dos círculos governamentais são o coração da Governance", o que requer uma nova e ampliada compreensão do papel das organizações públicas no seio da sociedade (WILLIAMSON, 2010; HEINRICH; LYNN; MILWARD, 2010). Em suma, o conceito de Governance afigura-se atualmente como alternativa ao paradigma managerialista e como seu sucessor em termos de repercussão mundial (VALLE, 2010; OSBORNE, 2010), passando o sector público a ser mais aberto à participação da sociedade civil (RHODES, 1997).

Voltando a Portugal e à reforma administrativa encetada nos últimos anos, temos que, no que concerne às privatizações, podemos indicar que a revisão constitucional de 1989 veio retirar o princípio da irreversibilidade das nacionalizações realizadas após a revolução de 1974, através da alteração do art. $^{\circ} 85^{\circ}$ da CRP, passando a constar a possibilidade de reprivatização "da titularidade ou do direito de exploração de meios de produção e outros bens nacionalizados depois de 25 de Abril de 1974", o que deu início ao processo de reprivatização que ainda hoje perdura -, permitindo uma rápida compressão do sector público produtivo (BILHIM, 2000a, 2000b). O objetivo político era claro: tornar possível um sistema de organização económica em que as regras do mercado livre tivessem um papel mais preponderante (TAVARES; ALVES, 2006). Acrescente-se que o recurso à privatização material do sector público foi muito utilizado em Portugal. Como constata Rolo (2002), o nosso país foi, em termos relativos, dos que mais privatizou, embora a grande preocupação se tenha cingido às receitas obtidas, descurando a 
obtenção de garantias quanto à modernização das entidades vendidas aos privados ou mesmo a melhoria do seu desempenho (SILVESTRE, 2008; ROLO, 2002). De frisar que é nesse período que se incrementam em Portugal outros tipos de privatização: os contratos de concessão, as parcerias entre o sector público com o privado e o não lucrativo. Por exemplo, assistiu-se a um imenso desenvolvimento das parcerias com as organizações particulares sem fins lucrativos para a implementação das políticas sociais (ARAÚJO, 2005).

No campo da "Orientação para o Cidadão" e "Desburocratização", existiram inúmeras iniciativas de reforma, das quais destacamos: a abertura de diversas Lojas do Cidadão, que concentram num só lugar e em horário alargado diversos serviços públicos, uma importante importação de boas práticas administrativas previamente testadas no Brasil (ARAÚJO, 2001); o programa INFOCID, relativo ao fluxo de informação para os cidadãos; seguido pela apresentação da Carta Deontológica e da Carta Ética do Serviço Público, que impôs aos funcionários públicos um conjunto de deveres para com os cidadãos; a publicação do Código do Procedimento Administrativo, através do Decreto-Lei n. ${ }^{\circ} 442 / 91$, de 15 novembro, que consagra direitos e garantias dos cidadãos perante o Estado, o que veio alterar as relações mantidas entre ambos, agora assente em diversos princípios (cf. art. ${ }^{\circ} 3 .^{\circ}$ a art. $^{\circ} 12^{\circ}$ ), com especial destaque para o princípio da colaboração do sector público para com os particulares (art. ${ }^{\circ} .^{\circ}$ ), bem como para o princípio da participação (art. ${ }^{\circ}$ 8. $^{\circ}$ ); a introdução do livro de reclamações no sector público (cf. Resolução do Conselho de Ministros n. ${ }^{\circ}$ 189/96, de 28 de novembro; Portaria n. ${ }^{\circ}$ 355/97, de 28 de maio; Decreto-Lei n. $135 / 99$, de 22 de abril); e, por fim, o programa de simplificação administrativa intitulado de SIMPLEX, embora este programa já tenha sido iniciado no século XXI (ONGARO, 2009; CARAPETO; FONSECA, 2006;NUNES, 2003). Os cidadãos estavam, pois, no centro destas reformas (ARAÚJO, 2005, 2001).

A partir do início do século $X X I$, iniciou-se uma viragem do foco das reformas administrativas para a eficiência, eficácia, economia e qualidade. Para tal, foram introduzidas no sector público ferramentas 
antes exclusivas do sector empresarial, tais como a gestão por objetivos, novos sistemas de avaliação de desempenho, novos estatutos para o emprego público, aproximando este da realidade do sector privado português, entre outras. O derradeiro objetivo é o mesmo do prosseguido pelas mais recentes reformas administrativas realizadas por esse mundo fora: redução das despesas públicas (MADUREIRA; FERRAZ, 2010A; ROCHA; ARAÚJO, 2007; ARAÚJO, 2005; POLLITT; BOUCKAERT, 2004).

Uma pertinente transformação foi a reorganização do Estado, encetada de 2004 em diante. Essa metamorfose iniciou-se com a Lei n. ${ }^{\circ} 3 / 2004$, de 15 de janeiro, que aprovou a lei-quadro dos institutos públicos, que mais não são do que agências executivas e instrumentos de flexibilização administrativa que conjugam a administração tradicional das organizações públicas com métodos do sector privado (CORTEREAL, 2008; SILVESTRE, 2008; ARAÚJO, 2002B); e com a Lei n. ${ }^{\circ}$ $4 / 2004$, de 15 de janeiro, que estabeleceu os princípios e normas a que deve obedecer a organização da administração direta do Estado. Posteriormente, deu-se o lançamento do Programa de Reestruturação da Administração Central do Estado (cf. a Resolução do Conselho de Ministros n. ${ }^{0}$ 124/2005, de 4 de agosto de 2005; e a Resolução do Conselho de Ministros n. ${ }^{\circ} 39 / 2006$, de 21 de abril), um programa ambicioso, global e centralmente projetado para rever a estrutura de todos os ministérios, com o objetivo de reduzir as estruturas e os cargos dirigentes, de forma a obter ganhos de eficiência pela simplificação e racionalização de estruturas, designadamente através do "recurso à descentralização para as autarquias locais, à desconcentração de serviços por forma a aproximá-los dos cidadãos, à externalização de funções para entidades privadas". Além disso, "preconiza-se a organização progressiva de serviços de partilha de funções e actividades comuns, o que permite aos demais serviços concentrar-se nos seus respectivos objectivos fundamentais" (CARAPETO; FONSECA, 2006, p. 34).

Os objetivos dessas recentes reformas estruturais passavam pela substituição das instituições altamente hierarquizadas e centralizadas por estruturas mais descentralizadas, por forma a racionalizar recursos 
e pela introdução de mecanismo de mercado no sector público, isto é, pretenderam alcançar um melhor aproveitamento dos recursos disponíveis, seja através da diminuição de estruturas e cargos de direção, seja através da criação de instituições com responsabilidade de administração centralizadas ou ainda através da diminuição de alguns dos benefícios existentes. Assim, o que se verificou é que a orientação estratégica dessas reformas se alicerça em alguns dos princípios que orientam a doutrina da NPM, principalmente a ênfase nos resultados. Tudo isso em nome de um sector público mais moderno (MENDES, 2010; FERRAZ; ALEXANDRE, 2008).

Outras das alterações foi ao nível da reforma da função pública, um dos aspetos essenciais da reforma administrativa portuguesa, se considerarmos, como o fez Nunes (2009), que Portugal é um dos países da zona euro em que a despesa com a remuneração dos funcionários públicos tem maior peso na economia, relativamente ao Produto Interno Bruto, o que terá contribuído para os défices excessivos, face às regras da União Europeia, recorrentemente apresentados.

Alterações ao nível do funcionalismo público já tinham sido encetadas anteriormente, através de um progressivo abandono dos vários aspetos regulatórios da função pública que transitaram do regime do Estado Novo, designadamente o peculiar regime de taxação já referido - ou de não taxação para ser mais exato -, o sistema de pensões de reforma e a ausência de qualquer sistema de avaliação de desempenho (CORTE-REAL, 2008). Para contornar essas questões e dignificar o emprego público, foram vários os diplomas legais que introduziram mudanças no sistema de carreiras, no recrutamento, na promoção e mobilidade do pessoal, sem esquecer as alterações do sistema retributivo (NUNES, 2009; ARAÚJO, 2005). Embora seja indiscutível na ótica de Rocha $(2010,2009)$ que as alterações realizadas tenham representado um importante avanço no sentido de uma maior racionalização e clarificação relativamente ao modelo anterior, também é verdade que as carreiras eram quase exclusivamente o único instrumento de administração de pessoal à disposição dos administradores, o que impedia claramente uma articulação entre a ARH e os objetivos da reforma administrativa, o que apenas vem demonstrar que a nova 
moldura penal não constituiu um instrumento assim tão inovador, no sentido da modernização, como à primeira vista podia parecer, talvez por não ter sido acompanhado doutras medidas mais incisivas. Resultado: esse novo modelo "apenas" veio estruturar o caraterístico sistema de carreiras da função pública portuguesa. Dessa forma, conforme refere Mendes (2010), a função pública portuguesa carateriza-se por ser muito pouco flexível e hierárquica, bem como pela sua cultura legalista e rígida. Isto é, assenta num protótipo de um sistema administrativo weberiano muito forte, o que não se compactua com uma função pública moderna.

Tendo isso em consideração, temos de ponderar o facto de a reforma da função pública só se ter efetivado através da publicação recente de diversa legislação, o que denota uma aproximação ao regime de emprego do sector privado, racionalização de gastos e procura de ganhos de eficiência, visando uma solução para o já crónico problema orçamental português. Declaração importante, porquanto define de forma clara o objetivo desse novo ímpeto reformatório, identificando-o claramente com os princípios da NPM (ROCHA, 2010; ROCHA;ARAÚJO, 2007). Em suma, em termos gerais, os principais diplomas legais que surgiram a partir desse novo contexto ideológico, e que representam a maior reforma da função pública portuguesa contemporânea, foram os seguintes:

- Lei n. ${ }^{\circ}$ 2/2004, de 15 de janeiro: aprova o estatuto do pessoal dirigente dos serviços e organismos da administração central, regional e local do Estado.

- Lei n. ${ }^{0} 53 / 2006$, de 7 de dezembro: estabelece o regime comum de mobilidade entre serviços dos funcionários e agentes da administração pública, visando o seu aproveitamento racional.

- Lei n. ${ }^{\circ}$ 52/2007, de 31 de agosto: adapta o regime da Caixa Geral de Aposentações ao regime geral da segurança social em matéria de aposentação e cálculo de pensões.

- Lei n. ${ }^{0}$ 12-A/2008, de 27 de fevereiro: estabelece os regimes de vinculação, de carreiras e de remunerações dos trabalhadores que exercem funções públicas. 
- Lei n. ${ }^{\circ} 58 / 2008$, de 9 de setembro: aprova o estatuto disciplinar dos trabalhadores que exercem funções públicas.

- Lei n. ${ }^{\circ}$ 59/2008, de 11 de setembro: aprova o regime do contrato de trabalho em funções públicas.

À lista anterior deve ser aditada a Lei n. ${ }^{\circ}$ 10/2004, de 22 de março, que criou o Sistema Integrado de Avaliação do Desempenho da Administração Pública (SIADAP), o qual surgiu associado ao congelamento das progressões automáticas e regulares baseadas na antiguidade. Para Madureira e Ferraz (2010a), o SIADAP constitui mesmo uma das mais notáveis reformas realizadas no sector público português de inspiração managerialista, pois revela a introdução da gestão por objetivos nesse sector, o que pode ser considerada uma matriz de mudança ao ligar os objetivos aos resultados obtidos, procurando introduzir uma cultura de mérito e de avaliação de resultados.

Posteriormente, através da Lei n. ${ }^{\circ} 66-\mathrm{B} / 2007$, de 28 de dezembro, deu-se à reestruturação desse sistema de avaliação de desempenho. Embora se mantenham as mesmas siglas (SIADAP), este passou a intitular-se "Sistema Integrado de Gestão e Avaliação do Desempenho na Administração Pública". De acordo com o seu artigo 9, o SIADAP integra os seguintes subsistemas, que funcionam de forma integrada: Subsistema de Avaliação do Desempenho dos Serviços;Subsistema de Avaliação do Desempenho dos Dirigentes; Subsistema de Avaliação do Desempenho dos Trabalhadores.

Convém aqui realçar que o Subsistema de Avaliação do Desempenho dos Serviços assenta num Quadro de Avaliação e Responsabilização (QUAR), sujeito à avaliação permanente e atualizado a partir dos sistemas de informação do serviço, em que se evidenciam: a missão do serviço; os objetivos estratégicos plurianuais determinados superiormente; os objetivos anualmente fixados e, em regra, hierarquizados; os indicadores de desempenho e respetivas fontes de verificação; os meios disponíveis, sinteticamente referidos; o grau de realização de resultados obtidos na prossecução de objetivos; a identificação dos desvios e, sinteticamente, as respetivas causas; a avaliação final do desempenho do serviço. 
Uma das maiores virtudes desse sistema decorre precisamente da promessa de transparência e da participação dos cidadãos. Isso resulta do QUAR, como instrumento de governação, traduzir os objetivos principais de cada organização pública para o curto/médio prazo, em termos de eficiência, eficácia, economia e qualidade. Dessa forma, o QUAR proporciona aos cidadãos e a outros stakeholders diversa informação relevante e precisa acerca das organizações públicas, designadamente quanto aos seus objetivos e metas e aos seus recursos humanos e financeiros. É essa abordagem que leva a que Madureira e Ferraz (2010a) defendam que estamos perante uma aproximação ao paradigma da Governance por parte da reforma administrativa portuguesa, embora frisem que, tal como em outros países e experiências, a baixa cultura cívica e de participação por parte dos cidadãos pode levar a que o QUAR não passe de mais um instrumento produzido pelo sector público para o sector público. De forma a evitar tal situação, e atendendo às preposições e objetivos do QUAR, esses autores entendem que seria útil no contexto do paradigma da Governance que o controlo, avaliação e accountability de todas as organizações públicas se realizassem sob o auspício de entidades independentes, de forma a se realizarem inquestionáveis avaliações e de se responsabilizar os dirigentes públicos pelos resultados obtidos.

\section{A terceira vaga: 2008 até ao presente}

A necessidade de contenção orçamental tem sido o foco principal do debate político em Portugal nos últimos anos (PEREIRA; PEREIRA, 2008), visto que os problemas orçamentais portugueses (défice público excessivo, aumento exponencial da despesa pública, incluindo os gastos com o pessoal etc.) já existem - e prevalecem - desde há muito (cf. CUNHA; BRAZ, 2006). Contudo, foi um advento de cariz global que colocou na ordem do dia essas dificuldades, tendo marcado toda a reforma administrativa portuguesa prosseguida desde esse marco até aos nossos dias: a crise financeira e económica global que se iniciou em 2008. Assim, embora a palavra "crise" já fizesse parte do léxico corrente dos portugueses há alguns anos, desde o colapso financeiro 
mundial de 2008, ela adquiriu um novo significado. Para compreender a magnitude da crise financeira atual, podemos indicar que, para muitos, ela representa o maior desastre e colapso financeiro desde a Grande Depressão, que se iniciou em 1929 (FRIEDMAN; FRIEDMAN, 2010; CROTTY, 2009). O que começou como uma crise financeira (crise do subprime no território norte-americano) rapidamente se transformou numa crise económica que se disseminou por qualquer país ou entidade económica aberto à globalização. Volvidos três anos desde o seu início, essa crise estendeu-se e sofreu nova mutação: desbocou numa crise de dívida soberana, em parte por causa da transferência da dívida privada para o sector público; embora em alguns países específicos a crise da dívida soberana deriva muito do sobre-endividamento estatal, como é o caso português (LODGE; HOOD, 2012).

Contudo, mais do que dissecar as causas dessa crise, o que nos interessa aqui é analisar as suas consequências, particularmente no caso do sector público português e, em última instância, da administração dos recursos humanos públicos. Assim, deixaremos de parte profetizações e opiniões como as de Kotz (2009, p. 316): em resultado da presente crise, "o movimento socialista poderá renascer nos próximos anos, abrindo, desta forma, a porta à possibilidade de finalmente estarmos perante o fim da era capitalista"; e nos cingiremos ao presente e aos factos concretos.

A realidade é que as consequências dessa crise global vão muito além dos aspetos económicos (PETERS; PIERRE; RANDMALIIV, 2011), induzindo uma renovada avaliação do papel do Estado e do sector público, sem esquecer a importância da governação para o desempenho económico (LODGE; HOOD,2012; ANDREWS; BOYNE; WALKER, 2011; MCNUTT; PAL, 2011). Esses aspetos levaram a que, em muitos países, tenha-se assistido a uma concentração do poder e do controlo nos Ministros das Finanças dos governos em exercício, tal e qual como aconteceu em Portugal, sendo que tal concentração tem por base a justificação de que é um meio necessário para resolver a crise (PETERS 5., 2011).

O efeito dessas transformações na própria Ciência daAdministração Pública levou Talbot (2009, p. 167) a colocar a questão: "será que estamos 
prestes a entrar numa nova erada administração pública?". Por outro lado, no espaço europeu - não só, mas principalmente -, as autoridades nacionais têm sido fortemente induzidas e, por vezes, obrigadas a adotar drásticos planos de austeridade, dos quais se destacam os cortes na despesa pública, através de reformas administrativas, por um lado; e o aumento das receitas públicas, mormente através do aumento da carga fiscal, por outro (BOYER, 2012). Lodge e Hood (2012, p. 80) compartilham dessa opinião, estendendo-a para além do espaço europeu: os cortes nos salários e pensões generalizaram-se, embora com intensidade, composição e timing variáveis; "as medidas iniciais, muitas vezes envolvendo congelamentos salariais, foram rapidamente seguidas demais cortes nos salários e pensões". Da leitura do Quadro 1 , podemos retirar algumas indicações dos pacotes de austeridade que recaíram diretamente sobre os funcionários públicos.

Quadro 1 - Medidas de austeridade que incidem diretamente sobre o funcionalismo público dos países da OCDE

\begin{tabular}{|c|c|}
\hline Medida de Austeridade & aíses \\
\hline Congelamento de salários & $\begin{array}{l}\text { Bulgária (2011-2013), Itália (2010-2013), Polónia } \\
\text { (2011), Eslovénia (2011), França (2011-2013), } \\
\text { Luxemburgo (2010), Reino Unido (2010-2012), } \\
\text { Espanha (2010) }\end{array}$ \\
\hline Corte de salários & $\begin{array}{l}\text { Alemanha }(2,5 \%) \text {, Irlanda (15\%), Grécia (15\%, com } \\
\text { cortes de } 8 \% \text { em subsídios e cortes de } 10 \% \text { nas } \\
\text { pensões), Portugal ( } 3,5 \% \text { a } 10 \% \text { em } 2010) \text {, Croácia } \\
(6 \% \text { em } 2009) \text {, Bulgária }(10 \% \text { em } 2010) \text {, Roménia } \\
(25 \% \text {, com cortes de } 15 \% \text { em benefícios), Espanha } \\
(5 \%) \text {, Hungria }(8 \%) \text {, Estónia }(8 \%) \text {, Letónia }(15-50 \%) \text {, } \\
\text { Lituânia }(11 \%)\end{array}$ \\
\hline $\begin{array}{l}\text { Cong } \\
\text { contre }\end{array}$ & $\begin{array}{l}\text { Áustria, Canadá, França, Grécia (2010), Irlanda, } \\
\text { Itália, Japão, Espanha, Portugal }\end{array}$ \\
\hline Planos de downsizing & $\begin{array}{l}\text { Irlanda (12\% entre } 2010-2014) \text {, Holanda (15\% } \\
\text { em } 4 \text { anos), Polónia }(10 \%) \text {, Reino Unido ( } 23 \% \text { no } \\
\text { governo central), Grécia (20\% entre } 2011-2013) \text {, } \\
\text { Roménia( } 15 \%) \text {, Estónia15,5\%(2007-2010), Japão } \\
\text { (5\%desde } 2005) \text {, Eslovénia ( } 1 \% \text { ao ano desde } \\
2004) \text {, Alemanha (até } 6 \% \text { ao longo de 4anos), } \\
\text { Estónia (11\%2008-2010), Letónia (29\%) }\end{array}$ \\
\hline
\end{tabular}

Fonte: Adaptado de Lodge e Hood (2012, p. 80). 
Centrando-nos novamente no plano europeu, os primeiros esforços nesse sentido, todavia, provaram ser insuficientes para aplacar a ansiedade da comunidade financeira internacional. Assim, nessa conjuntura, tanto a União Europeia como o FMI foram chamados para apoiar e acompanhar o processo de ajustamento da Grécia, da Irlanda e, finalmente, de Portugal (BOYER, 2012).

Não obstante a relutância cada vez maior para com as medidas de austeridade e as recorrentes chamadas de atenção dos seus efeitos nefastos, tanto a nível social como económico; da apresentação de soluções alternativas baseadas no crescimento económico e do emprego; ou mesmo na reformulação do projeto europeu e de uma maior solidariedade intraeuropeia (cf. BOYER, 2012), a realidade é que elas existem e estão a ser aplicadas em Portugal, via acordo com a Troika. Muitas delas incidem diretamente no sector público e nos seus funcionários, através de cortes na despesa prevista no Orçamento de Estado, inclusive cortes salariais, congelamento de progressões e promoções na carreira, perda do subsídio de férias e de Natal etc.; o que terá efeitos contundentes na motivação e satisfação dentro da Função Pública portuguesa, bem como na própria avaliação de desempenho dos funcionários públicos.

Muitas das medidas que passamos a apresentar não ocorreriam, seguramente, se não estivéssemos perante uma implacável crise económica e financeira no nosso país e que exigem rigorosas e austeras medidas para a combater. É como referem Peters et al. (2011, p. 16): a crise é "uma oportunidade para membros do governo poderem realizar alterações que não seriam possíveis sem a [sua] existência".

Assim, o atual Governo Constitucional, devido à forte crise económica que afeta Portugal, tem sido marcado, como já referimos, pelas fortes medidas de austeridade que têm vindo progressivamente a ser adotadas. Assim, no âmbito dessas medidas, e com relevo para o emprego público, podemos, desde logo, apontar a tomada de decisão do corte dos subsídios de férias e de Natal a funcionários públicos ou aposentados, através da Lei do Orçamento de 2012 - Lei n. ${ }^{\circ}$ 64-B/2011, de 30 de dezembro, nos seus artigos $21^{\circ}$ e $25^{\circ}$. 
No entanto, um grupo de deputados à Assembleia da República requereu ao Tribunal Constitucional, ao abrigo do disposto na alínea a), do $n .^{\circ} 1$, e na alínea f) do $n^{\circ} 2$, do artigo $281 .^{\circ}$, da CRP, e do $n^{\circ} 1$, dos artigos $51^{\circ}$ e $62^{\circ}$, da Lei n. ${ }^{\circ} 28 / 82$, de 15 de novembro, a declaração de inconstitucionalidade, com força obrigatória geral, das normas constantes dos artigos $21^{\circ}$ e $25^{\circ}$, da Lei n. ${ }^{\circ} 64-B / 2011$, de 30 de dezembro.

A 5 de julho de 2012, o Tribunal Constitucional declarou, no Acórdão do Tribunal Constitucional n. ${ }^{\circ}$ 353/2012, Processo n. ${ }^{\circ}$ 40/12, a inconstitucionalidade da suspensão do pagamento dos subsídios de férias ou de Natal a funcionários públicos ou aposentados, sobretudo por violação do Princípio da Igualdade, consagrado no artigo $13^{\circ} \mathrm{da}$ CRP, sobretudo, porque, como refere o Acórdão citado, "há um esforço adicional em benefício de todos, em prol da comunidade, que é pedido exclusivamente aos servidores públicos", mas determinam que os efeitos dessa decisão não tenham efeitos para o corrente ano.

Encontram-se previstas outras medidas de austeridade na Lei do Orçamento do Estado de 2012. Estamos, nomeadamente, a referir-nos às seguintes medidas de congelamento do valor nominal das pensões para o ano de 2012, ou seja, não serão as mesmas objeto de atualização, nos termos do artigo $80^{\circ}$ da Lei do Orçamento para 2012, bem como à manutenção da proibição de revalorizações remuneratórias para o ano de 2012. Ou seja, o actual Governo decidiu manter a interdição de revalorizações remuneratórias durante o programa de ajustamento, o que já resultava do artigo $24^{\circ}$ (Proibição de valorizações remuneratórias), da Lei do Orçamento de 2011 - Lei n. ${ }^{\circ}$ 55-A/2010, de 31 de Dezembro -, mantendo-se esse artigo ainda em vigor nos temos do artigo $20 .^{\circ}$ da Lei do Orçamento de Estado de 2012 (artigo este que apresenta uma epígrafe curiosa: Contenção da despesa, que expressa bem, a nosso ver, a realidade em que vivemos).

As restrições às novas contratações para a função pública são reais, existindo um controlo do recrutamento de trabalhadores que praticamente veda novas contratações. Só em casos excecionais, desde que se verifiquem certos requisitos cumulativos, podem os membros do 
Governo responsáveis pelas áreas das Finanças e da Administração Pública autorizar a abertura de procedimentos concursais com vista à constituição de relações jurídicas de emprego público (ou seja, ao recrutamento de novos trabalhadores), nos termos do n. ${ }^{\circ} 1$ e n. ${ }^{\circ} 2$, do artigo $9 .^{\circ}$, da Lei n. ${ }^{\circ} 12-\mathrm{A} / 2010$, de 30 de junho - lei que aprovou um conjunto de medidas adicionais de consolidação orçamental que visam reforçar e acelerar a redução de défice excessivo e o controlo do crescimento da dívida pública previstos no Programa de Estabilidade e Crescimento, na redação que Ihe foi conferida pelo artigo $37 .^{\circ}$ da Lei n. ${ }^{\circ}$ 64-B/2011, de 30 de dezembro. Aliás, o rol das entidades públicas obrigadas a esta contenção foi alargado através dos artigos $28 .^{\circ}$ e $45 .^{\circ}$ da já citada Lei n. ${ }^{\circ}$ 64-B/2011, de 30 de dezembro. O claro objetivo dessa política de (quase) congelamento das admissões na função pública portuguesa cumpre dois propósitos: conter (ou diminuir) o valor da despesa pública e - a partir de maio de 2011 - cumprir com o ponto 3.49 do memorando de entendimento estabelecido com a Troika, ou seja, "limitar as admissões de trabalhadores na administração pública, com vista a atingir decréscimos anuais em 2012-2014 de 1\% por ano na administração central e de $2 \%$ por ano nas administrações regional e local".

Por fim, refira-se que se manteve a redução de salários que já vigorava em 2011. Assim, com a Lei do Orçamento do Estado para 2011 - nos termos do artigo $19^{\circ}$ (redução remuneratória) - o Executivo de José Sócrates definiu cortes salariais no Estado para os funcionários que ganham acima de 1.500 euros brutos. O atual Governo decidiu manter os cortes durante o programa de ajustamento. O corte varia entre 3,5\% e $10 \%$, sendo o patamar mais baixo aplicado às remunerações que se situam entre os 1.500 euros e os 2.000 euros - nos termos do n. ${ }^{0} 1$, do artigo $20^{\circ}$, da Lei do Orçamento de Estado para 2012, que mantém em vigor o citado artigo $19^{\circ}$, da anterior Lei do Orçamento.

Ainda a propósito da problemática da redução salarial dentro do sector público português levanta-se uma questão pertinente: a fuga dos melhores para o sector privado. Dito de outra forma, dentro da função pública portuguesa convivem duas realidades distintas, a saber: por um 
lado, tanto os indivíduos que ocupam cargos dirigentes como aqueles que se encontram incluídos na carreira de técnico superior - funções que exigem qualificações académicas, científicas ou técnicas especializadas, portanto - ostentam níveis remuneratórios inferiores às suas contrapartes do sector privado, enquanto os funcionários incluídos nas carreiras de assistente técnico e assistente operacional, exercendo por isso funções meramente administrativas, indiferenciadas e auxiliares têm um nível remuneratório igual ou mesmo, em alguns casos, superior (OCDE, 2012; CAMPOS; PEREIRA, 2009; FERNANDES, 2003; CAMPOS, 2002). Retirando da equação outras variáveis como sejam a motivação para o serviço público ou as particularidades inerentes ao contrato psicológico do sector público, esta desvantagem salarial registada entre os cargos com maior grau de formação e de maior complexidade técnica, em conjunto com o aumento da carga de trabalho, poderá mesmo colocar em causa, de acordo com a OCDE (2012), a capacidade de execução das políticas públicas prosseguidas por parte da administração central, o que, convenhamos, não deixará de ser irónico.

No entanto, apesar de alguns problemas quanto aos resultados destas reformas, há que assinalar a inversão de uma situação que já durava há mais de 50 anos: inverteu-se a tendência de constante subida do número de funcionários públicos (ROCHA, 2010).

Tabela 1 - Evolução do número de funcionários públicos em Portugal

\begin{tabular}{ccccccccccc}
\hline 1968 & 1979 & 1983 & 1986 & 1988 & 1991 & 1996 & 1999 & 2005 & 2007 & 2009 \\
\hline Total 196.755 & 372.086 & 420.304 & 464.321 & 485.368 & 509.732 & 638.674 & 716.418 & 737.774 & 708.567 & 690.198 \\
\hline
\end{tabular}

Fonte: Adaptado de Rocha $(2010,74)$

A realidade é que essas medidas podem não ser suficientes. Os países da zona Euro que se encontram mais vulneráveis a essa crise financeira, económica e de dívida soberana, incluindo Portugal, podem ainda assistir a mais e severas restrições. Caso esses países permaneçam na zona Euro, os seus serviços públicos sentirão novas e drásticas reduções de salários e de outros benefícios, cuja natureza era, até há pouco, considerada impensável nas democracias modernas com 
remanescência do Estado Providência (PIERSON, 1995). Por outro lado, se sairmos, ou formos "convidados" a sair da zona Euro, os efeitos no sector público e nos seus funcionários serão semelhantes ou ainda mais graves perante as consequências desse cenário (LODGE; HOOD,2012).

\section{Entraves e obstáculos à introdução dos novos paradigmas de administração pública no sector público português}

Os entraves e obstáculos às tentativas de abraçar as novas ideologias da NPM e Governance foram muitos, em grande parte por culpa da forte cultura conservadora das instituições públicas portuguesas e da forte tradição legalista do sector público português, o que, aliás, é uma caraterística transversal a toda a sociedade portuguesa. A maioria das reformas ou mudanças na economia e na sociedade ocorrem dentro de um quadro jurídico específico e centralizado. Intenções - e até mesmo programas - tendem a ser pré-anunciado por novas leis, regras e regulamentos. A implementação de tais regras é, por vezes, lenta, para além de ser habitual existir uma lacuna entre a lei e a realidade. No entanto, a fórmula utilizada é recorrente: estudos começam ao nível dos gabinetes, comissões ou da administração; conclusões são obtidas a um nível político; nova legislação é preparada e aprovada. A implementação recai sobre os administradores não sendo, às vezes, muito bem-sucedida. Dito isso, podemos considerar que algumas das dificuldades de implementação derivam de uma preparação legislativa e de um processo de elaboração que não inclui uma real avaliação do impacto regulamentar, para além de nem sempre ter em conta os reais problemas que deveriam ser resolvidos (CORTE-REAL, 2008). Kickert (2007) partilha da mesma opinião, embora o seu enfoque seja mais genérico, não incidindo apenas sobre Portugal mas abarcando todos os países com influências napoleónicas. Assim, para este autor, embora os princípios da NPM estejam presentes nas reformas encetadas por esses países, como a remuneração com base no desempenho, a avaliação do desempenho, orientação para os resultados, entre outros, a verdade é que as reformas não alteram substancialmente o paradigma 
legalista tradicional, sendo estas como que absorvidas pelo legalismo e pelo formalismo. Na mesma direção concorreu Rocha (2009: 119), ao defender que, em Portugal, a "força da cultura organizacional burocrática (mecanicista) tende a absorver todas as mudanças", ou seja, a bloqueálas, congelando particularmente aquelas que se revistam de um carácter estrutural (MADUREIRA; FERRAZ, 2010b).

Tudo isso contribuiu para que ainda continue a persistir um excesso de burocracia (MAIA; MACHADO, 2002), falta de flexibilidade e uma insuficiente atenção para com o comportamento organizacional e com as estruturas de incentivo (TAVARES; ALVES, 2006). Esses entraves e obstáculos levaram a que muitas das reformas anteriormente referidas e apresentadas não tenham atingido os seus objetivos iniciais. Tal pode ser inferido através da quantidade e qualidade dos problemas que persistem dentro do sector público português e que foram apontadas recentemente por Corte-Real (2008): défices orçamentais excessivos, muito além dos requisitos incluídos no Pacto de Estabilidade da União Europeia; excessivo número de funcionários públicos, não obstante a redução encetada a partir de meados da primeira década do século XXI; as remunerações e indemnizações concedidas a certos (poderosos) grupos introduziram desigualdade e turbulência na despesa pública; embora juridicamente legítima, a influência política sobre a nomeação de administradores de topo lança a suspeita e a falta de confiança dentro da área de atuação da esfera pública, para além da falta de credibilidade no processo de reforma.

Nunes (2004, p. 62) tinge de negro o processo reformatório português das transatas décadas. Nas suas palavras, a reforma administrativa em Portugal foi uma realidade "mas sem medidas de fundo e uma estratégia continuada". Bilhim (2001, p. 79) carateriza exemplarmente tal realidade: essa "revolução talvez se tenha feito sentir muito do lado académico (investigação e ensino), pouco do lado dos profissionais (quem no dia-a-dia administra a coisa pública) e nada do lado do cidadão (razão de ser da administração)." 
Corte-Real (2008) identificou as decisões políticas como causa principal para a vil inércia e marasmo que modelaram este desprestigiante panorama. Nas últimas décadas, o discurso político sempre foi coerente com as abordagens racionalista e lógica da administração da qualidade para um sector público eficaz e eficiente. No entanto, existe uma lacuna entre o que é oficialmente declarado e o que é realmente posto em prática. Os persistentes problemas no sector público correspondem a decisões políticas que foram feitas por diferentes governos e partidos políticos: devido à forte cultura legalista existente, anteriormente referida, o aspeto legal prevalece sobre a administração e a maioria das decisões relacionadas com as questões anteriormente referidas são tomadas ao nível do Conselho de Ministros e até mesmo da Assembleia da República. Assim, a nosso ver, os políticos têm, ou tiveram, uma elevada responsabilidade para o atual estado de coisas.

Posto isso, temos de considerar que continuam a subsistir no sector público português elementos do Paradigma Clássico de Administração Pública, lado a lado com os princípios das doutrinas da NPM e do paradigma da Governance. Na verdade, do trabalho de CorteReal (2008), consubstanciado pela opinião de Ongaro (2008), podemos retirar evidências que apontam no sentido da coexistência de elementos derivados da NPM com elementos de cariz tradicional e influenciados pelo modelo napoleónico.

Tal não é inédito ou insólito: muito embora as organizações estejam organizadas e atuem em busca de diferentes valores em momentos diferentes, a verdade é que, durante o período em que uma ideia é dominante (neste caso específico estamos a falar das ideias da NPM e Governance), as outras conceções e ideias nunca são totalmente negligenciadas (Kaufman, 1956). Por outras palavras, a adoção de um dado modelo de administração pública não significa que partes importantes da atividade do Estado não sigam modelos diferentes (TRUSS, 2008; ROCHA, 2000). Chiavenato (2008) refere que os diversos modelos de administração pública se sucedem no tempo, sem que, no entanto, qualquer um deles seja inteiramente abandonado. Por exemplo, atualmente, ao mesmo tempo que a atenção dos académicos 
se está a direcionar para as abordagens preconizadas e defendidas pela Governance e que as ferramentas e princípios oferecidos pela NPM estão a ser abertamente contestadas (FATTORE et al., 2012), o interesse pelos preceitos da NPM não se evaporou e está para continuar (FERLIE; FITZGERALD, 2002). Em resumo, e em jeito de conclusão, "elementos de cada um destes [três] modelos frequentemente coexistem ou sobrepõem-se" (OSBORNE, 2006; p. 378). Em resumo, o modelo burocrático persiste, e continuará a persistir, tanto em sectores públicos objeto de reformas administrativas baseadas nos valores e práticas da NPM e/ounas doutrinas da Governance. É isso que acontece no nosso país e do qual não nos podemos esquecer.

\section{Discussão, conclusões, limitações do trabalho e pistas para futura investigação}

A evolução da $\mathrm{ARH}$ no sector público português nas últimas quase quatro décadas foi deveras impressionante. Todavia, para melhor compreendermos, temos, invariavelmente, de ter em consideração as sucessivas reformas administrativas encetadas pelos diversos governos desde que o golpe militar de 25 de Abril de 1974 deu por terminado o regime ditatorial do Estado Novo, reformas que incluem transfigurações à $\mathrm{ARH}$, prosseguida pelas instituições públicas portuguesas. Dessa feita, uma das principais ilações a retirar desse processo reformatório interrupto é francamente simples, embora funesta: cada uma das sucessivas vagas reformatórias foram idealizadas e concebidas para contrabalançar, ou mesmo impugnar, as anteriores intenções reformistas. Excetuando a orientação para cidadão, "não é possível vislumbrar qualquer continuidade real" desse processo reformatório (CORTE-REAL, 2008, p. 220). Outra conclusão a retirar: não segue o mesmo padrão que a maioria dos países da OCDE (ARAÚJO, 2005), até porque ela se inseriu, inicialmente, num contexto de transição para a democracia, um processo que representa, em muitos aspetos, um desafio muito maior do que uma reforma administrativa que simplesmente tem de responder às pressões globais no quadro de um sistema político-administrativo 
estável (ONGARO, 2008, p. 102). Em primeiro lugar, diverge em termos temporais, ou seja, enquanto noutros pontos do globo as reformas do sector público iniciaram-se entre finais da década de setenta e inícios da década de oitenta do século transato, "a um nível pragmático, em Portugal, é apenas na década de 90 que as ideias de renovação da administração pública começam a ser expressas de forma mais articulada e sistematizada" (MADUREIRA; CAMPOS, 2000, p. 186). Por outro lado, inicialmente, muitas destas reformas, ao invés de combater o Estado Providência - ponto fulcral nas reformas administrativas prosseguidas noutros países no mesmo período temporal -procuraram melhorar a administração tradicional em vez de recriar o papel do Estado e racionalizar o funcionamento do sector público. No entanto, tanto a crise que se instalou no início deste século, como o défice das contas públicas e a pressão da União Europeia para o equilíbrio dessas mesmas contas públicas levaram os responsáveis políticos a repensar a estratégia seguida, designadamente quanto ao papel do Estado e à dimensão do sector público (ROCHA; ARAÚJO, 2007, p. 589-590), isto é, passou a ser primordial a mudança de um sistema excessivamente "formal, centralizador e burocrático, flagelado por normas e regulamentações, [com] um rígido sistema orçamental rígido e de pessoal e que está preocupado como controlo legal" (ARAÚJO, 2002b, p. 226), exibindo, desta forma, muitas das caraterísticas associadas ao Paradigma Clássico da Administração (ARAúJO, 2001).

A resposta dos responsáveis políticos portugueses perante essas vicissitudes - pré e pós crise financeira de 2008 - foi dada através de uma real influência dos paradigmas da NPM e Governance na reforma administrativa portuguesa, tendo esta incidido fortemente na lógica do mercado, com privatizações, criação de agências independentes, maioritariamente sob a forma de instituto público, contratualismo etc.; nas iniciativas participacionistas, redução do perímetro do sector público, prevalecendo a orientação para o cliente e o utente, a instância de reclamação, avaliação da qualidade dos serviços etc.; e as iniciativas de desregulamentação e desburocratização, através da simplificação de procedimentos, estatuto do funcionário público, 
flexibilização na relação laboral, entre outras (NUNES, 2009). Araújo (2005; 2002b) detém a mesma visão desse processo reformatório, pois, de acordo com ele, podem ser encontradas nas reformas prosseguidas diversas cateterísticas inerentes à NPM, como seja: a orientação para os resultados e clientes; o esforço para mudar os valores e atitudes; a qualidade nos serviços e a procura de um melhor desempenho; a preocupação com o pragmatismo; uma preocupação pela redução das despesas públicas; as privatizações, nas suas diversas formas; os processos de descentralização e desconcentração, incluindo a criação de agências autónomas, designadamente os institutos públicos, muito influenciada pelas experiências noutros países; ultrapassar os entraves burocráticos à mudança; e pela necessidade de ultrapassar os rigorosos constrangimentos do direito administrativo relativamente à administração das instituições públicas, incluindo a administração de pessoal; a gestão por objetivos e a avaliação do desempenho daí decorrente, entre outros. Resumindo, em Portugal, a NPM adquiriu um estatuto notável ao longo do fim do século $X X$ e do início do século $X X I$, independentemente das críticas que foram sendo direcionadas, tanto pela comunidade científica como pela experiência empírica, relativamente às falhas desse modelo (MADUREIRA; FERRAZ, 2010b).

Com relação ao paradigma da Governance, podemos contemplar as suas influências nas parcerias com o sector privado no processo de operacionalização de algumas políticas públicas, como seja a implementação das políticas sociais através, por exemplo, do Programa da Rede Social. De acordo com o Decreto-Lei n. ${ }^{\circ}$ 115/2006, de 14 de junho, esse programa não é mais do que uma parceria entre entidades públicas e privadas com intervenção nos mesmos territórios, isto é, um fórum de articulação e congregação de esforços baseado na adesão por parte das autarquias e de entidades públicas ou privadas com vista à erradicação ou atenuação da pobreza e da exclusão e à promoção do desenvolvimento social. Trata-se, então, de uma responsabilização e mobilização do conjunto da sociedade e de cada indivíduo para o esforço de erradicação da pobreza e da exclusão social em Portugal. Outro indício da presença das ideias do paradigma da Governance 
será o apelo à participação dos cidadãos e à accountability democrática inerente a ferramentas como o QUAR.

Ora bem, como não poderia deixar de ser, a evolução da ARH do sector público seguiu de perto as vicissitudes e as linhas gerais do processo reformatório mencionado. Nos anos imediatos à Revolução de Abril de 1974, a principal preocupação era a reforma do desatualizado e obsoleto regime da função pública que vinha do Estado Novo. A resposta foi a criação de um sistema de carreiras públicas, com procedimentos e condições comuns quanto ao ingresso e recrutamento, bem como de regras bem delineadas quanto ao progresso dentro das carreiras, mobilidade do pessoal, sem esquecer as alterações do sistema retributivo. A pertinente questão que daqui decorre é esta: a nova arquitetura do funcionalismo público português não se afastava muito ao preconizado e defendido pelo Paradigma Clássico da Administração. Dito de outra forma, ao invés de se registar uma aproximação às - então - emergentes ideias managerialistas, do que mais tarde foi designado por NPM, a opção foi usar como fonte os ideais burocráticos do paradigma clássico da administração, o que resultou numa função pública pouco flexível, hierárquica, rígida e com uma especial apetência pela cultura legalista e onde as carreiras eram quase exclusivamente o único instrumento de administração de pessoal à disposição dos administradores públicos. O contraciclo português, quando o paralelo de referência são outros países de cariz ocidental, também pode ser vislumbrado no número de funcionários públicos. Ao contrário do que acontecia na maioria dos países ocidentais, o número de funcionários públicos portugueses disparou na década de 80 e de 90 do século XX.

Esse panorama apenas se alterou já no presente século, através da publicação de diversa legislação em que se torna evidente uma aproximação ao regime de emprego do sector privado, racionalização de gastos e procura de ganhos de eficiência, cuja base eram os princípios doutrinários da NPM. Dentro delas, um claro destaque tem de ser dado à introdução da gestão por objetivos quando da criação do SIADAP, que não é mais do que um processo de envolvimento dos objetivos da organização por todos os seus intervenientes, estabelecendo resultados 
a serem alcançados, para além de se dimensionarem as respetivas contribuições e de se proceder ao sistemático acompanhamento do desempenho, isto é, a intenção aquando da introdução deste sistema de avaliação era o de procurar introduzir uma cultura de mérito e de avaliação de resultados no sector público português.

Os últimos anos foram marcados pela austeridade resultante do descontrolo das contas públicas portuguesas aliado à maior crise financeira e económica mundial desde a Grande Depressão de 1929. Restringindo a nossa apreciação à função pública portuguesa de salientar que esta foi alvo de várias medidas elencadas para fazer face ao presente cenário negro e cujo único propósito será a diminuição da despesa pública, o que tem vindo a ser conseguido através de medidas como cortes salariais, congelamento de progressões e promoções na carreira, restrições a novas contratações, perda do subsídio de férias e de Natal etc.

Nesse epílogo, não poderíamos deixar de escrever algumas palavras sobre os obstáculos que se colocaram no caminho das reformas atrás mencionadas, muitos deles derivando da forte cultura organizacional burocrática e tradição legalista que continuam a persistir nas instituições públicas portuguesas. Assim, a maioria das reformas ou mudanças na economia e na sociedade são introduzidas no sistema jurídico através de um quadro jurídico de novas leis, regras e regulamentos etc. Além disso, muitas vezes, a implementação de tais regras é lenta, para além de ser habitual existir um caminho, por vezes longo, a percorrer entre a lei e a realidade. A conjunção desses fatores tem vindo a contribuir sobremaneira para que ainda hoje continue a persistir um excesso de burocracia, inflexibilidade e uma exígua atenção para com o comportamento organizacional e estruturas de incentivo. Dito de outra forma, a verdade é que as reformas não alteram substancialmente o paradigma legalista tradicional, sendo como que absorvidas pelo legalismo e pelo formalismo.

Na sequência do que vem exposto, podemos extrair que o modelo burocrático continua a persistir no sector público português, mesmo que 
algum espaço tenha sido ocupado por valores e práticas da NPM e da Governance, nomeadamente ao nível da ARH. Em síntese, "elementos de cada um destes [três] modelos frequentemente coexistem ou sobrepõem-se" (OSBORNE, 2006, p. 378). Sendo este o status quo de Portugal, seria importante, pensamos nós, encontrar soluções concretas e a curto prazo que eliminem de uma vez por todas os resquícios burocráticos que ainda persistem entre nós e que são um claro obstáculo à introdução das reformas já referenciadas, ou seja, no fundo entraves à evolução do País, pelo menos no âmbito da atividade administrativa.

Embora todo esse processo de reforma administrativa do sector público português, com especial destaque para a $\mathrm{ARH}$, tenha sido alvo de um enquadramento histórico, político, económico e social, uma limitação deste trabalho é a falta de uma maior contextualização nestas óticas para os períodos temporais aqui em investigação. Tal empreitada permitiria - talvez - uma melhor compreensão do teor das reformas da $\mathrm{ARH}$ ocorridas no sector público português. Outra limitação decorre da vertiginosa sucessão de acontecimentos pautados pela incerteza patente nos dias que correm, o que levará a uma rápida desatualização deste trabalho, no que às mais recentes reformas diz respeito.

Em termos de pistas de pesquisa futuras, um dos caminhos a seguir poderá ser o de estudos comparativos a nível internacional, principalmente com outros países europeus que se debatem atualmente com as mesmas (ou similares) dificuldades a nível económico e financeiro (cf. Grécia, Espanha, Irlanda ou Itália), o que permitiria comparar as políticas prosseguidas quanto à administração dos seus recursos humanos públicos e os resultados obtidos das mesmas em termos de eficácia, eficiência e economia. Circunscrevendo-nos a Portugal, é notória a falta de um estudo que averigue as reais consequências e alcance das diversas vagas reformatória que se sucederam ao nível da $\mathrm{ARH}$, o que abre espaço a investigações neste prisma. 


\section{Referências}

ANDREWS, R.; BOYNE, G. A.; WALKER, R. M. Dimensions of publicness and organizational performance: a review of the evidence. Journal of Public Administration Research and Theory, Lawrence, v. 21, n. 3, p. 301-319, 2011. Suplemento.

ARAÚJO, J. E. A avaliação da gestão pública: a administração pós burocrática. Comunicação apresentada na Conferência da UNED, Corunha, Espanha, 21 de Novembro, 2007. Disponível em: <http:// repositorium. sdum.uminho.pt/handle/1822/8309>. Acesso em: 5 ago. 2010.

ARAÚJO, J. E. Os dirigentes na relação entre a administração e os cidadãos. Revista de Administração e Políticas Públicas, Braga, v. 3, n.1/2, p. 28-35, 2002a.

ARAÚJO, J. E. Improving public service delivery: the crossroads between NPM and traditional bureaucracy. Public Administration, Malden, v, 79, n. 4, p. 915-932, 2001.

ARAÚJO, J. E. NPM and change in portuguese central government. International Public Management Journal, London, v. 5, n. 3, p. 223236, 2002b.

ARAÚJO, J. E. A reforma administrativa em Portugal: em busca de um novo paradigma. Working Paper do Núcleo de Estudos em Administração e Políticas Públicas da Universidade do Minho, Série I, n. 10, 2005. Disponível em: <http://www3.eeg.uminho.pt/riap/neapp /plataforma/modulos/comum/scripts/visitante_construtor_pagina. php5?modulo=documentos\&script=informacao_documento\&id_ menu=323\&coluna=3\&nome_categoria=Documentos+de+Trabalho>. Acesso em: 5 ago. 2010.

ARAÚJO, J. E. A reforma da gestão pública: do mito à realidade. Comunicação apresentada no Seminário Internacional Luso-Galaico: A reforma da Administração Pública apostas e casos de sucesso, Braga, 
18 a 19 maio, 2004. Universidade do Minho. Disponível em: <http:// repositorium.sdum.uminho.pt /handle/1822/3312>. Acesso em: 29 jul. 2010.

AUCOIN, P. The new public management: Canada in comparative perspective. Montreal: Institute for Research on Public Policy, 1996.

AUER, A.; DEMMKE, C.; POLET, R. Civil services systems in European of fifteen: current situation and prospects. Maastricht: EIPA, 1996.

BACH, S.; BORDOGNA, L. Varieties of new public management or alternative models? The reform of public service employment relations in industrialized democracies. The International Journal of Human Resource Management, London, v. 22, n. 11, p. 2281-2294, 2011.

BARZELAY, M. The new public management: improving research and policy dialogue. Berkeley: University of California Press, 2001.

BILHIM, J. A administração reguladora e prestadora de serviços. In: PEREIRA NETO, João et al. (Org.). Fórum 2000: reformar a administração pública: um imperativo. Lisboa: Instituto Superior de Ciências Sociais e Políticas, 2000a. p. 145-171.

BILHIM, J. Gerir a administração pública como uma empresa. In: PEREIRA NETO, João et al. (Org.). Fórum 2000: reforma do estado e administração pública gestionária. Lisboa: Instituto Superior de Ciências Sociais e Políticas, 2001. p. 77-84.

BILHIM, J. Reduzir o insustentável peso do estado para aumentar a leveza da administração. Revista de Administração e Políticas Públicas, Braga, v. 1, n. 1, p. 18-37, 2006b.

BOYER, R. The four fallacies of contemporary austerity policies: the lost Keynesian legacy. Cambridge Journal of Economics, Cambridge, v. 36, n. 1, p. 283-312, 2012.

BROWN, K. Human resource management in the public sector. Public Management Review, Philadelphia, v. 6, n. 3, p. 303-309, 2004. 
CAMPOS, A. F. C. (2002) Reforma da administração pública: dos estereótipos à viabilidade. In: TAVARES, Luis Valadares; MATEUS, Abel; CABRAL, Francisco Sarsfield (Org.). Reformar Portugal: 17 estratégias de mudança. Lisboa: Oficina do Livro, 2002. p. 169-194.

CAMPOS, M. M.; PEREIRA, M. C. Wages and incentives in the portuguese public sector. Economic Bulletin (Banco de Portugal), Lisboa, v. 15, n. 2, p. 57-77, 2009.

CARAPETO, C.; FONSECA, F. Administração pública: modernização, qualidade e inovação. 2. ed. Lisboa: Silabo, 2006.

CERVO, A. L.; BERVIAN, P. A. Metodologia científica. 5. ed. São Paulo: Makron Books, 2002.

CHIAVENATO, I. Administração geral e pública. 2. ed. Rio de Janeiro: Elsevier, 2008.

CORTE-REAL, I. Public management reform in Portugal: successes and failures. International Journal of Public Sector Management, v. 21, n. 2, p. 205-229, 2008.

CROTTY, J. Structural causes of the global financial crisis: a critical assessment of the new financial architecture. Cambridge Journal of Economics, Cambridge, v. 33, n. 4, p. 563-580, 2009.

CUNHA, J. C.; BRAZ, C. R. Public expenditure and fiscal consolidation in Portugal. OECD Journal on Budgeting, Paris, v. 6, n. 4, p. 103-121, 2006.

DENHARDT, J. V.; DENHARDT, R. B. The new public service: serving, not steering. Edição expandida. New York: M. E. Sharp, 2007.

DENHARDT, R. B.; DENHARDT, J. V. The new public service: serving rather than steering. Public Administration Review, Philadelphia, v. 60, n. 6, p. 549-559, 2000.

FATTORE, G.; DUBOIS, H. F. W.; LAPENTA, A. Measuring new public management and governance in political debate. Public Administration Review, Philadelphia, v. 72, n. 2, p. 218-227, 2012. 
FERLIE, E.; FITZGERALD, L. The sustainability of the new public management in the U.K. In: MCLAUGHLIN, Kate; OSBORNE, Stephen P.; FERLIE, Ewan (Org.). New public management: current trends and future prospects. London: Routledge, 2002. p. 341-353.

FERNANDES, E. Condições de emprego, carreiras e motivação dos funcionários. In: CONGRESSO NACIONAL DE ADMINISTRAÇÃO PÚBLICA, 2003, Oeiras. Anais... Oeiras: Instituto Nacional de Administração, 2003. p. 159-165. Tema: Os vectores da mudança.

FERRAZ, D.; ALEXANDRE, H. Que espaço para uma cidadania activa e participativa no contexto das reformas da administração pública em Portugal?". In: CONGRESSO NACIONAL DE ADMINISTRAÇÃO PÚBLICA, 6., 2008, Lisboa. Disponível em: <http://repap.ina.pt/ handle/10782/568>. Acesso em: 14 mar. 2008.

FRANCO, A. S. A experiência revolucionária. In: REIS, António (Org.). Portugal: 20 anos de democracia. Lisboa: Círculo de Leitores, 1994. p. 176-205.

FRIEDMAN H. H.; FRIEDMAN, L. W. Lessons from the global financial meltdown of 2008. Journal of Financial Transformation, New York, v. 28, p. 45-54, 2010.

GRAND, J.; BARTLETT, W. Introduction. GRAND, J.; BARTLETT, W. (Org.). Quasi-markets and social policy. Basingstoke: Macmillan Press, 1993. p. 1-13.

GREENAWAY, J.; SALTER, B.; HART, S. How policy networks can damage democratic health: a case study in the government of governance. Public Administration, Malden, v. 85, n. 3, p. 717-738, 2007.

HEINRICH, C. J.; LYNN, L. E.; MILWARD, H. B. A state of agents? Sharpening the debate and evidence over the extent and impact of the transformation of governance". Journal of Public Administration Research and Theory, Lawrence, v. 20, n. 1, p. 3-19, 2010. 
HOOD, C. The art of the state: culture, rhetoric, and public management. Oxford: Oxford University Press, 1998.

HOOD, C. Contemporary public management: a new global paradigm. Public Policy and Administration, London, v. 10, n. 2, p. 104-117, 1995b.

HOOD, C. The new public management in the 1980's: variations on a theme. Accounting, Organization and Society, Oxford, v. 20, n. 2/3, p. 93-109, 1995a.

HOOD, C. A public management for all seasons?. Public Administration, Malden, v. 69, n. 1, p. 3-19, 1991.

HOOD, C.; JACKSON, M. Administrative argument. Aldershot: Dartmouth Publishing Group, 1991.

KABOOLIAN, L. The new public management: challenging the boundaries of the management vs. administration debate. Public Administration Review, Malden, v. 58, n.3, p. 189-193, 1998.

KAUFMAN, H. Emerging conflicts in the doctrines of public administration. American Political Science Review, Washington, DC, v. 50, n. 4, p. 1057-1073, 1956.

KETTL, D. F. The global revolution in public management: driving themes, missing links. Journal of Policy Analysis and Management, Bloomington, v. 16, n. 3, p. 446-462, 1997.

KICKERT, W. J. H. Public management in the United States and Europe. In; KICKERT, W. J. H. (Org.). Public management and administrative reform in Western Europe. Cheltenham: Edward Elgar, 1997. p. 15-38.

KICKERT, W. J. H. Public management reforms in countries with napoleonic state model: France, Italy and Spain. In: POLLITT, Christopher; THIEL, Sandra Van, HOMBURG, Vincent (Org.), New public management in Europe: adaptation and alternatives. New York: Palgrave MacMillan, 2007. p. 26-51. 
KOTZ, D. M. The financial and economic crisis of 2008: a systemic crisis of neoliberal capitalism. Review of Radical Political Economics, Amherst, v. 41, n. 3, p. 305-317, 2009.

KOURGANOFF, W. A face oculta da universidade. Tradução de Cláudia Schilling e Fátima Murad. São Paulo: Ed. Unesp, 1990.

LANE, J. The public sector: concepts, models and approaches. 3. ed. London: Sage, 2000.

LODGE, M.; HOOD, C. Into an age of multiple austerities? Public management and public service bargains across OECD countries. Governance: An International Journal of Policy, Administration, and Institutions, Malden, v. 25, n. 1, p. 79-101, 2012.

LÖFFLER, E. Public governance in a network society. In: BOVAIRD, Tony; LÖFFLER, Elke (Org.). Public management and governance. $2^{\text {nd }}$ ed. New York: Routledge, 2009. p. 215-232.

LYNN, L. E. The new public management: how to transform a theme into a legacy". Public Administration Review, Malden, v. 58, n. 3, p. 231-237, 1998.

LYNN, L. E. Public management: a concise history of the field. In: FERLIE, Ewan; LYNN JUNIOR, Laurence E.; POLLITT, Christopher (Org.). The Oxford handbook of public management. New York: Oxford University Press, 2005. p. 27-50.

MADUREIRA, C.; CAMPOS, A. C. A formação superior em administração pública em Portugal. Revista de Administração e Políticas Públicas, Braga, v. I, n. 2, p. 185-194, 2000.

MADUREIRA, C.; FERRAZ, D. As configurações políticoadministrativas e a seleção de dirigentes. Sociologia, Problemas e Práticas, Lisboa, n. 63, p. 51-69, 2010b.

MADUREIRA, C.; FERRAZ, D. The need of a XXI century governance paradigm for public administrations: the specific case of Portugal. Public Policy and Administration (Viešoji Politika Ir Administravimas), Vilnius, n. 31, p. 35-48, 2010a. 
MAIA, S. I. S.; MACHADO, C. F. S. C. Motivação e satisfação na administração pública: análise de um caso. In: ENCONTRO INA: A reinvenção da função pública: da burocracia à gestão , 3., 2002, Oeiras. Anais... Oeiras: Instituto Nacional de Administração, 2002. p. 407-427.

MCNUTT, K.; PAL, L. A. Modernizing government: mapping global public policy networks. Governance: An International Journal of Policy, Administration, and Institutions, Malden, v. 24, n. 3, p. 439-467 2011.

MENDES, S. M. Policy autonomy in public sector agencies. European Group for Public Administration. Comunicação apresentada no EGPA Annual Conference - Toulouse 8 a 10 Setembro 2010. Acesso em: 3 jan. 2011. Disponível em: <http://soc.kuleuven.be/io/egpa/ org/2010Toul/Papers/Silvia_M_Mendes_EGPA\%202010.pdf > . Acesso em: 3 jan. 2011.

NUNES, P. O perfil dos dirigentes no actual contexto da nova gestão pública em Portugal: especial referência aos cargos de escolha pública. 2003. 563 f. Tese (Doutorado em Gestão)- Instituto Superior de Ciências do Trabalho, Lisboa, 2003.

NUNES, P. Reforma do emprego público: breves considerações às grandes reformas em curso em Portugal”. Tékhne, Barcelos, v. VII, n. 11, p. 49-73, 2009.

NUNES, P. Sebenta de organização e gestão pública. Barcelos: Escola Superior de Gestão do Instituto Politécnico do Cávado e do Ave, 2004. v. I.

OCDE OECD Economic Surveys: Portugal - overview.

2012. Disponível em: <http://www.oecd.org/ eco/

economicsurveysandcountrysurveillance/ PORTUGAL_2012_Overview. pdf>. Acesso em: 6 set. 2012.

ONGARO, E. Introduction: the reform of public management in France, Greece, Italy, Portugal and Spain”. International Journal of Public Sector Management, v. 21, n. 2, p. 101-117, 2008. 
ONGARO, E. Management reform and modernization: trajectories of administrative change in Italy, France, Greece, Portugal and Spain. Cheltenham: Edward Elgar Publishing, 2009.

OSBORNE, S. P. The new public governance? Public Management Review, Philadelphia, v. 8, n. 3, p. 377-387, 2006.

OSBORNE, S. P. Public governance and public services delivery: a research agenda for the future. In: OSBORNE, S. P. (Org.). The new public governance? Emerging perspectives on the theory and practice of public governance. London: Routledge, 2010. p. 413-428.

PEREIRA, A. M.; PEREIRA, R. M. Controlling the public wage bill in Portugal: the case of university professors. Applied Economics Letters, v. 15, n. 3, p. 997-1000, 2008.

PETERS, B. G. The future of governing: four emerging models. Lawrence: University Press of Kansas, 1996.

PETERS, B. G. The politics of bureaucracy. 5th ed. London: Routledge, 2001.

PETERS, B. G.; PIERRE, J.; RANDMA-LIIV, T. Global financial crisis, public administration and governance: do new problems require new solutions? Public Organization Review, Amsterdam, v. 11, n. 1, p. 13$27,2011$.

PIERSON, P. Dismantling the welfare state. Cambridge: Cambridge University Press, 1995.

PINTO, M. L. R. As tendências demográficas. In: REIS, António (Org.). Portugal: 20 anos de democracia. Lisboa: Círculo de Leitores, 1994. p. 296-306.

POLLITT, C. Convergence: the useful myth? Public Administration, Malden, v. 79, n. 4, p. 933-947, 2001.

POLLITT, C. Managerialism and the public service: the anglo-american experience. Cambridge: Basil Blackwell, 1990. 
POLLITT, C.; BOUCKAERT, G. Public management reform: a comparative analysis. $2^{\text {nd }}$ ed. Oxford: Oxford University Press, 2004.

RAINEY, H. G. Using comparisons of public and private organizations to assess innovative attitudes among members of organizations. Public Productivity \& Management Review, Middletown, v. 23, n. 2, p. 130149, 1999.

RAINEY, H. G.; CHUN, Y. H. Public and private management compared. In: FERLIE, Ewan; LYNN JUNIOR, Laurence E.; POLLITT, Christopher (Org.). The Oxford handbook of public management. New York: Oxford University Press, 2005. p. 72-102.

RAUPP, F.; BEUREN, I. Metodologia da pesquisa aplicável às ciências sociais. In: LONGARAY, André Andrade et al. (Org.). Como elaborar trabalhos monográficos em contabilidade: teoria e prática. 3. ed. São Paulo: Atlas, 2006. p. 76-97.

RHODES, R. A. W. Understanding governance: policy networks, governance, reflexivity and accountability. Buckingham: Open University Press, 1997.

ROCHA, J. A. O. Gestão de recursos humanos na administração pública. 3. ed. Lisboa: Escolar, 2010.

ROCHA, J. A. O. Gestão pública e modernização administrativa. Lisboa: INA, 2009.

ROCHA, J. A. O. Modelos de gestão pública. Revista de Administração e Políticas Públicas, Braga, v. I, n. 1, p. 6-16, 2000.

ROCHA, J. A. O. Princípios de gestão pública. Lisboa: Presença, 1991.

ROCHA, J. A. O.; ARAÚJO, J. E. Administrative reform in Portugal: problems and prospects. International Review of Administrative Sciences, Brussels, v. 73, n. 4, p. 583-596, 2007.

ROLO, J. M. Doze anos de privatizações em países da OCDE. Revista Portuguesa e Brasileira de Gestão, Lisboa, v. I, n. 3, p. 26-30, 2002. 
ROSENBLOOM, D. H.; KRAVCHUCK, R. S.; CLERKIN, R. M. Public administration: understanding management, politics, and law in the public sector. 7. ed. New York: McGraw-Hill, 2009.

RUBIN, E. V.; KELLOUGH, J. E. Does civil service reform affect behavior? Linking alternative personnel systems, perceptions of procedural justice, and complaints. Journal of Public Administration Research and Theory, Lawrence, v. 22, n. 1, p. 121-141, 2012.

SHAFRITZ, J. M. A behavioral analysis for the public service. New York: Praeger Publishers, 1973.

SILVERMAN, D. Interpreting qualitative data. $2^{\text {nd }}$ ed. London: Sage, 2001.

SILVESTRE, H. M. C. A reforma do sector público sob influência do modelo gestionário: o caso das águas em Portugal. 2008. 559 f. Tese (Doutorado em Ciências da Administração)-Escola de Economia e Gestão da Universidade do Minho, Braga, 2008.

SULEIMAN, E. Dismantling democratic states. Princeton: Princeton University Press, 2003.

TALBOT, C. Public value: the next "big thing" in public management? International Journal of Public Administration, London, v. 32, n. 3/4, p. 167-170, 2009.

TAVARES, J. F. F. Gestão pública, cidadania e cultura de responsabilidade. In: MOZZICAFREDDO, Juan; GOMES, João Salis; BATISTA, João S. BATISTA (Org.). Ética e administração: como modernizar os serviços públicos? Oeiras: Celta, 2003. p. 17-30, 2003.

TAVARES, L. V.; ALVES, A. A. The future of portuguese public administration and a new agenda for public administration science in the 21 st century. Public Administration, Malden, MA, v. 84, n. 2, p. 389406, 2006.

TRUSS, C. Continuity and change: the role of the HR function in the modern public sector. Public Administration, Malden, MA, v. 86, n. 4, p. 1071-1088, 2008. 
VALLE, V. R. L. Direito fundamental à boa administração e governança: democratizando a função administrativa. 2010. 254 f. Tese (PósDoutorado em Administração)-Escola Brasileira de Administração Pública e de Empresas, Rio de Janeiro, 2010.

WILLIAMSON, A. R. Public organizations as principals in an era of new governance: evidence from the U.S. low income housing tax credit program. International Journal of Public Administration, London, v. 33, n. 11, p. 551-563, 2010.

Artigo recebido em: 12/06/2013

Aprovado em: 27/12/2013 